\title{
Aspects of our Savior's activity as a Teacher
}

\author{
Fr. PhD. Florin VÂRLAN \\ Faculty of Theology and Sciences of Education \\ Valahia University of Târgovişte \\ ROMANIA \\ E-mail: varlanflorin@yahoo.com
}

\begin{abstract}
When we talk about the redeeming work of our Savior Jesus Christ, we have in view His three ministries: that of teacher or prophetic, the one of overseer (archbishop) and that of leader or king. These three ministries define His redeeming work, which is one and unique and is turned to the human nature that He assumed and then to all of us, who are His fellows, and, at the same time, to God as sacrificial attitude, Christ being "the Lamb of God, Who wipes away the world's sin" (Jn. 1: 29) and brings to us our reconciliation with God the Father.Our Savior Christ has fulfilled His ministry as a teacher directly, namely preaching He Himself the truth of the Evangel, yet, in an indirect manner, His work has been continued, in the Church, through the Apostles and their followers, the bishops and priests whom the Holy Spirit will illuminate for an uninterrupted and correct preaching of the divine truth, until the end of the centuries, according to the commandment that He has given to His disciples: "Therefore go and make disciples of all nations, baptizing them in the name of the Father and of the Son and of the Holy Spirit; teaching them to observe everything that I have commanded you. And remember, I am with you all the days, to the end of the age. Amen." (Mt. 28: 19-20).
\end{abstract}

Keywords: Evangel; teaching; Savor; example; theology;

\section{INTRODUCTION}

The redeeming work of Jesus Christ can be viewed from these three perspectives of it (teacher, archbishop and king), yet without separating them, each being found in the other, and all together being intertwined in:

\footnotetext{
"The sacrifice of His own body, the teaching and example of ministry given to the people and the power He exerts on nature by miracles, on death by Resurrection and on people by the commandments and the power He is giving them for their redemption"
}

In the connection between them, these three forms of ministry are intertwined, so that one can say that our Savior "is teaching by serving, is sacrificing Himself defeating the consequences of sin, and dominates like a stabbed Lamb” (Revelation 5).

This work is continued by our Savior after His Ascension to heaven, in the Church, by the Holy Spirit. So, as a prophet, He is teaching, making known to man, in the highest degree and in the most accessible way, the Being and the will of God and the work of salvation. As an Archbishop, He restores the connection between man and God, reconciling,

\footnotetext{
${ }^{1}$ Pr. Prof. Dr. Dumitru STĂNILOAE, Teologia Dogmatică Ortodoxă, vol. II, ediția a II-a, EIBMBOR, București, 1997, p. 76.
} 
by His supreme sacrifice, God with man, because we "are sanctified by the sacrifice of Jesus Christ's body, once and for all", Who "offering one sacrifice for sins, sat down forever on the right side of God" (Hebrews 10: 10, 12).

By the Embodied Son, man has the possibility to know God, to find out the true theology, as much as necessary, the divine teaching preached by our Savior Christ being "the words of eternal life" (Jn. 6: 68). By their content, the evangels become the culmination of the revelation, all the other writings of the New Testament having as fundament the Person of Jesus Christ, truly God and truly Man, under all the three aspects of His Messianic activity: teacher, king and archbishop.

As a Teacher, our Savior shows that theology is not a simple reflection on what Divinity means, but a way of living led in a personal relationship with God, Whom $\mathrm{He}$ presents is His quality of Father, a life that starts by obeying (the commandments), is nourished by faith and ends by eternal life: "I tell you the solemn truth: the one who hears My message and believes the One Who sent Me has eternal life and will not come into judgement but has passed from death to life." (Jn. 5: 24). In his quality of Leader and King, Christ reveals Himself as the Way to the true knowledge: "I am the Way, the Truth and the Life" (Jn. 14: 6); He is the door that leads to the Father: "I am the gate. If anyone enters through me, he will be saved; he will come in and will be saved" (Jn. 10: 9).

\title{
1. OUR SAVIOR - THE TEACHER BY EXCELLENCE
}

Our Savior Jesus Christ is the Teacher by excellence ${ }^{2}-$ Rabbi, as He Himself shows Himself to be: "You have but one teacher: Christ." (Mt. 23: 8, 10); He is the supreme Teacher and Prophet ${ }^{3}$. About no other teacher has anyone said that: "never has a man spoken like this Man" (Jn. 7: 46). By this, it is shown that He is "the One and only", yet not in the sense of "singularity or exclusivity", as Father Constantin Galeriu writes, "but of supreme revealer of the truth"

Regarding this aspect, Father Dorin Opriș considers:

\begin{abstract}
"By His uniqueness, one must not understand, by no means, the desire of being the only preacher of the whole truth, transmitted with power to be able to awaken and purify the spirits to make them partakers of the Truth",5.
\end{abstract}

He is not a teacher like any other man, but, in the activity He fulfills, He impresses on this mission of teacher the highest degree possible. Father Prof. Dumitru Stăniloae says in this sense:

\section{"He is the Teacher, in the supreme sense, by His very Person, because out of His Person springs His teaching, showing man's true way to the perfect eternity of the existence" 6 .}

Amazed by the teachings it was listening and by the wonderful acts it was seeing, the people calls our Savior Jesus Christ "Prophet" (Luke 7: 16) and "Teacher" (Jn. 6: 14), the prophet announced by Moses (Deut. 18: 15-18), and so do the Apostles but also His adversaries who were calling Him "Teacher" (Mt. 8: 19; Mk. 10: 35). Since then and forever

\footnotetext{
${ }^{2}$ Pr. Lect. Dr. Vasile Gordon, Predica Ocazională (pareneza), E.I.B.M.B.O.R., București, 2001, p. 172.

${ }^{3}$ Pr. Prof. Dr. Dumitru StăniloAe, op. cit., p. 78.

${ }^{4}$ Pr. Prof. Dr. Constantin GALERIU, Mântuitorul Iisus Hristos, Învățătorul nostru suprem, in rev. "Ortodoxia", no. $1 / 1983$, p.34.

${ }^{5}$ Dorin OPRIȘ, Dimensiuni creștine ale pedagogiei moderne, ediția a III-a, Ed. Didactică și Pedagogică, R. A., București, 2012, p. 85.

${ }^{6}$ Pr. Prof. Dr. Dumitru StĂNiloAe, op. cit., p. 79.
} 
He remained the Prophet of the truth and the Teacher of the world, the prophet of all the prophets and the Teacher of all the teachers, His teaching being, first of all, His very Person ${ }^{7}$. But Christ is not just a simple teacher of the law or just any prophet, but the Teacher by excellence, the prototype of perfection of the Christian. This truth is confessed by the evangelist Matthew who wrote that: “... the crowds were amazed at His teaching, for He was teaching them as one who had authority, and not as their scribes." (Mt. 7: 28-29).

The prophetic call of our Savior is His activity of teacher and discoverer of the absolute religious truth about God, of the moral norms, confirming everything also by His Life, as the supreme example of perfect life: "Again Jesus spoke to them, saying, "I am the light of the world. The one who follows me will never walk in darkness, but will have the light of life." (Jn. 8: 12). Just as the prophets of the Old Testament, chosen and sent by God to announce Him and His will, to guide the people and to watch over its religious and moral life, similarly Jesus Christ, as a prophet, teaches the divine truth, which He illustrates by His own life, a true example of perfection in virtue for us.

\footnotetext{
"Just as the prophets of the Old Testament, who would prove that they were sent by God by miracles and prophecies, our Savior also accompanies His preaching by performing miracles and by announcing future events, such as those regarding the fall of Jerusalem and the life of the Church"s.
}

But Christ is not like the other prophets. He is the prophet of the prophets, because the other prophets are announcing and teaching the world by the power given to them by God; Christ, being Himself God, announces His own things, which are also those of the Father.

\begin{abstract}
"He is identified with His teaching. And His teaching can only spring from Him. He is the Prophet in a unique and supreme sense. (...) He is the One Who preaches and the One Who Preaches Himself. He is even, by this, the Prophet by excellence, because His teaching shows the true way for making humanity perfect. And in this He only translates Himself, since He is the way to perfection and perfection itself"'.
\end{abstract}

Having the qualities of a perfect educator, the Lord Christ has been called the Pedagogue in the patristic literature. Clement of Alexandria, in the work bearing this title, explains why only the Savior can be called this way:

\footnotetext{
"The Pedagogue is Jesus. Sometimes He calls Himself a Shepherd, saying: «I am the Good Shepherd» (Jn. 10: 11-14). According to a metaphor, starting from the shepherds taking care of the sheep, Jesus ... is the Pedagogue leading us, the children, to salvation. The Logos stated by Hosea very clearly about Him, saying: «I am your teacher.»" (Hosea 5: 2) ${ }^{10}$.
}

Even since the Old Testament, the Great Prophet is announced by the prophets. Moses forewarns the children of Israel about the coming in their midst of a prophet greater than himself Whom they will need to obey: "A prophet like me will the Lord, your God, raise up for you from among your own kindred; that is the one to whom you shall listen." (Deut. 18: 15), prophetic words also confirmed afterwards by Yahweh - the Almighty God,

\footnotetext{
${ }^{7}$ Ilarion V. FELEA, Duhul Adevărului, Editura Diecezana, Arad 1943, p. 88, apud. Nicolae CodreA: Iisus Hristos Învăţătorul, în opera lui Ilarion V. Felea, http://www.agoracrestina.ro/biblioteca/nicolae_codrea-iisus-hristosinvatatorul-in-opera-lui-ilarion-v-felea-.html, accessed on 12.06.2016.

${ }^{8}$ Prof. N. ChIȚESCU, Pr. Prof. Isidor TOdORAn, Pr. Prof. I. Petreuță, Teologia dogmatică şi simbolică, vol. II, Ed.Renaşterea, Cluj-Napoca, 2005, p. 40.

${ }^{9}$ Pr. Prof. Dr. Dumitru STĂNILOAE, op. cit., p. 116.

${ }^{10}$ Clement AleXandrinul, Pedagogul, in Scrieri, partea I, trad. Dumitru Fecioru, colecția P.S.B., vol.4, E.I.B.M.B.O.R., București, 1982, p. 196.
} 
Who added that the New Prophet will speak what He will tell Him: "I will raise up for them a prophet like you from among their kindred, and will put my words into the mouth of the prophet; the prophet shall tell them all that I command" (Deut. 18: 18). Thus, these two Messianic texts highlight the prophetic ministry of our Savior Christ.

In the New Testament, Jesus is presented as the prophet of the last days, because "in these last days he has spoken to us by his Son, whom he appointed hair of all things, and through whom also he made the universe" (Hebr. 1: 2); He is indicated as Rabbi, teacher and great prophet, strong in acts and in deeds: "...Jesus of Nazareth, Who has been a prophet mighty in deed and word before God and all the people" (Luke 24: 19), Who by His coming in the world is leading us to the eternal life and is giving to us the power to see and understand the true God, because we know that "the Son of God has come and has given us discernment so that we may know him who is true; and we are in him who is true, in his Son Jesus Christ." (1 Jn. 5: 20). Christ is the perfect teacher on God's Being and will and the most skilled preacher of the Creator's vivifying word, which He is sharing to us directly.

As a Teacher, the Savior Christ reveals to the world the Evangel, namely the good news of the divine mercy bestowed upon man to redeem him, and the eternal truths regarding God's Person and His eternal Kingdom. In His mission, Christ our Lord has in view to transmit all that man needs to know about God, about the world, about himself, the essentials that will lead man to salvation.

\footnotetext{
“As God's Son, He reveals the glorified Triune God, as Logos, creator Word, He is giving to us the authentic sense of the creation, as Man's Son He is offering to us the model and the plenitude that the human person is called to attain"11.
}

A special feature of the activity of our Savior as a teacher, as Father Dumitru Călugăru highlights as well, is that He takes into account "the sense organ", namely the features and the specific of the audience: their occupation, their age or their culture. "For this reason, Jesus Christ is speaking to the ploughmen about the sower; to the workers of the vineyard, about their own occupation; to the fishermen, about the wonderful fishing. To Nicodemus (Jn. 3), who was erudite and pure at heart, He is offering a deep gaze into the plan of salvation even from the start of His activity. At the same time, to the Samaritan woman, who had an active spirit, a good soul, He reveals Himself as a Prophet and the true Messiah, by a dialogue led with great and deep psychology. He speaks in one way with $a$ legislator and in a different way with the Pharisees (Mt. 22: 41 and the next)"12.

Regarding His mission as a teacher, we need to say that our Savior did not write anything Himself, but only talked to the multitudes looking for Him, thirsty for His redeeming word. This call and attraction to His Person and His word reveal to us, in the didactic work of our Lord Jesus Christ, a spring full of life, conquering the mind, the heart and the will of the listeners. The Lord was speaking everywhere, at any time and on any occasion, yet He would take into account the circumstances in which He was speaking and the audience He was speaking to. He was speaking in one manner with the teachers of the law and the Pharisees, and in a different way with the people. There is one rule to remember. His word was simple and attractive. For this reason, the multitudes, namely large crowds, were following Him, and they were listening to Him so carefully that sometimes they even forgot about their hunger during the day, as it happened in the desert, with the five thousand

\footnotetext{
${ }^{11}$ Pr. Prof. Dr. Constantin GALERIU, art. cit, p. 37.

${ }^{12}$ Pr. Prof. Dumitru CĂLugĂRU, Catehetica, ediția a IV-a, Editura "Renașterea”, Cluj-Napoca, 2005, pp. 23-24.
} 
men, without counting the women and the children, who were filled to their full in a miraculous manner with five loaves of bread and two fish (Mt. 14: 13-21).

Saint Matthew the Evangelist synthesizes in a narrative summary the whole public activity of our Lord as follows: "And Jesus went throughout all Galilee, teaching in their synagogues and proclaiming the gospel of the kingdom and healing every disease and every sickness among the people." (Mt. 4: 23).

These three verbs-teach, proclaim and heal, underline the most important aspects of the Lord's activity: didactic, kerygmatic and therapeutic. The didactic activity of our Savior is synthesized by the Evangelist in the five great discourses included in his Evangel: The Sermon on the Mount (Mt. 5-7); The Apostolic or Missionary Discourse (Mt. 10), The Discourse in parables (Mt. 13: 1-52), The Discourse of the Church (Mt. 18) and The Eschatological Discourse (Mt. 24-25).

The First Evangel of the canon of the Holy Scripture presents Christ our Lord as a teacher rather than as a wonder-worker, teacher not just for the Jews but also for the people of all the times and all the places, to whom the celestial Father addresses the commandment: "Listen to Him!" (17: 5). Our Savior teaches us in His preaching about God, about the world, about man. As Son of God, He reveals to us the glorified Triune God, as creating Logos He gives meaning to our existence in the framework of creation, as Son of Man, He is offering to us the perfect model that humanity is called to attain.

Jesus Christ is the eternal Teacher exhorting us to salvation, out of His words springs directly His divinity, which we are enjoying by receiving the teaching of the Evangel. He is accomplishing His prophetic call directly, preaching He Himself the truth of His Evangel, yet, indirectly, His work is continued, in the Church, by the Apostles and their followers, the bishops and the priests, whom the Holy Spirit illuminates to preach uninterruptedly and correctly the divine truth, until the end of the ages, according to the commandment given by our Savior: "And remember, I am with you all the days, to the end of the age." (Mt. 28: 20).

\section{ASPECTS OF THE ACTIVITY AS A TEACHER (WAYS OF PRESENTING THE WORD: THE DIRECT SPEECH AND THE PARABLE)}

In His activity of Teacher of the world, the Savior speaks about God, about the world, about man. As Son of God, He reveals to us the glorified Triune God, as creating Logos He gives sense to our existence in the creation, as Son of Man, He offers to us the perfect model that humanity is called to attain.

"The truth preached by Him is, according to its content, the teaching about Himself, about His work and His kingdom and at the same time completion of the Mosaic law."13.

Wanting to present in one place several teachings of our Savior, Matthew the evangelist condensates in three chapters (5-7) a series of discourses grouped on certain themes. From the beginning, we need to mention that this group of discourses "is not the stenograph of that sermon, namely a rendering word by word but a well-delineated abstract ${ }^{\prime 14}$. At the same time, one must specify that many of these teachings are found as well in other circumstances in the evangels, though not in the same words, however in a very similar form.

\footnotetext{
${ }^{13}$ Hristu Andrutsos, Dogmatica Bisericii Ortodoxe răsăritene, Editura și tiparul Tipografiei Arhidiecezane, Sibiu, 1930, p. 225.

${ }^{14}$ Pr. Prof. Univ. Dr. Leon ARION, Comentarii la Sfânta Evanghelie după Matei, Ed. ASA, București, 2007, p. 141.
} 
The section in the Evangel according to Matthew is the first out of the five great literary units that the specialists call "speeches". This first discourse is also entitled "the sermon on the mount", according to the place where it was uttered, and it has a structure that can be divided into three parts: the disciples' status and mission (cf. Mt. 5: 1-48), the new lifestyle of the one who wants to follow God (cf. Mt. 6: 1-7, 12) and the true and the false prophets (cf. Mt. 7: 13-29). In their turn, these three parts can be divided into: the introduction of the sermon on the mount (cf. Mt. 5: 1-2), the beatitudes (cf. Mt. 5: 3-12), the disciples' mission (cf. Mt. 5: 13-16), Jesus Christ and the Law (cf. Mt. 5: 17-20), the antithesis of the discourse (cf. Mt. 5: 21-48), the disciples' way of life, which can be practiced by charity, prayer and fasting (cf. Mt. 6: 1-6, 16-18), the prayer model: Our Father (cf. Mt. 6: 7-15), the deliverance from earthly concerns (cf. Mt. 6: 19-34), charity and trust in God (cf. Mt. 7: 1-12), the two ways (cf. Mt. 7: 13-14), the false prophets (cf. Mt. 7: 15-20), the false disciples (cf. Mt. 7: 21-13), the house built on the rock (cf. Mt. 7: 24-27) and conclusion (cf. Mt. 7,28-29).

Viewed from the perspective of its situation in time, The Sermon on the Mount belongs to the beginning of the Lord's activity in Galilee, so to the beginning of the second year of evangelization, and concerning its content, we could say it has a face turned towards the disciples and another turned towards the multitudes, this is why any exegesis must take into account this fact, trying to go not just into the immediate, exterior (exoteric) aspects, turned to the multitudes, but especially into the deepest, interior (esoteric) ones, turned to those who make a greater effort of understanding and effectively follow Christ.

Concerning the place where this "sermon" may have been held, an old tradition mentions that it would be the mountain Kurun (Karn) Hattin, which will receive the name of The Mount of Beatitudes, a mount situated nor far from the city of Tiberias, just $560 \mathrm{~m}$ above the level of Lake Gennesaret ${ }^{15}$. It is on one of the two tops of this mount that our Lord Jesus Christ sat down, "and His disciples drew near Him and He opened His mouth and began to teach them" (Mt. 5: 1-2). According to the Oriental customs, our Savior taught sitting down; only in exceptional cases, when He wanted not just to be listened to, but also to involve His listeners in a direct manner or to defend Himself in front of His accusers, He spoke standing up (cf. Jn. 7: 37).

Jesus opens his speech with the presentation of nine ways of reaching beatitude, and here the term beatitude is another word for perfection, because beatitude is associated each time with the practice of a virtue, of a way to perfection whose target is the likeness of God (a fact resulting from the expressions: acquiring God's kingdom, seeing God etc.). Likening this speech to Moses' Decalogue, the Holy Fathers call The Sermon on the Mount: "Codex of the New Law" ". By this comparison between the essential teachings of the Old Testament and those preached by our Savior:

"He made the Old Law perfect, turning it into a superior and universal law, putting the accent on the love for God and for our fellow"17.

A special feature of our Savior's discourse is that his teaching is present both directly, the message being presented in a simple, easily understandable manner, and by

\footnotetext{
${ }^{15}$ Pr. Prof. Dr. Constantin CoRnițESCU, Studiul biblic al Noului Testament, Ed. Europolis, Constanța, 2005, p. 142.

${ }^{16}$ Ibidem, p. 114.

${ }^{17}$ Pr. Prof. Ioan Constantinescu, Studiul Noului Testament, E.I.B.M.B.O.R., București, 2002, p. 55.
} 
means of parables ${ }^{18}$, which are but comparisons, starting from images taken from the surrounding reality. Desiring to highlight the atmosphere dominating around the Teacher, the evangelist Matthew emphasizes that "He did not say anything to them without using a parable" (Mt. 13: 34).

Christ's pedagogical plan is clear: He speaks to the people, He shows to them the truth of faith, and He gives them the fruits to listen to Him. God's plan is always good: He first transmits something, man takes over the message, or not, then comes the lesson. The lesson can be towards progress, when man is receptive, or it can be painful, when man chooses the opposite of God's will. The elementary principle of classical education relied on listening and respect: the younger was supposed to listen to the older, the pupil was supposed to listen to the teacher, the student was supposed to listen to the professor, the disciple was supposed to listen to the master, in order to be able to learn and for education to become redeeming.

In the specialized language of the Christian pedagogy, this way of presenting the teaching is called the principle of intuition, and has in view the direct influence of the objects or phenomena of the surrounding world on the senses and by this on learning. Father Dorin Opriș notes:

"Since the true knowledge relies on sensitivity and reason, our Savior shows that the necessity of intuition is directly connected to the level of abstractization of the teaching"19.

To help His listeners understand the fact that the value of the human being and the care the Creator has for it is perfect, Christ our Lord intuitively starts from concrete aspects of life, such as the bird's food, the beauty of the lilies and of the field:

\begin{abstract}
"Look at the birds of the sky, they neither sow nor reap nor gather into barns and yet your heavenly Father feeds them. Are you not more valuable than they? And why are you anxious about clothing? Consider the lilies of the field, how they grow; they do not toil nor do they spin; but I say to you that not even Solomon in his entire royal splendor was clothed like one of these. Now if God so clothes the grass of the field, which is here today but tomorrow is thrown into the oven, will he not much more clothe you, O you of little faith?" (Mt. 6: 26, 28-30).
\end{abstract}

Speaking in parables, our Savior uses exemplifications from the daily life, realities known by the majority of the listeners who were part of simple social categories and who, by these methods, got to understand teachings on: behavior, morals, salvation, eternal life end the Kingdom of $\operatorname{God}^{20}$. In fact,

"in the authority with which Jesus speaks, and the power with which He acts, the Kingdom
of God is revealed. That Jesus goes to His death as King of Jews, predicting His resurrection
as Son of Man, is in harmony with the implication of His teaching that the Kingdom of God
come, with the coming of the Messiah"21.

\footnotetext{
${ }^{18}$ Like R. Zimmermann said, „A parable is a short narrative fictional text that is related in the narrated world to known reality but, by way of implicit or explicit transfer signals, makes it understood that the meaning of the narration must be differentiated from the literal words of the text. In its appeal structure it challenges the reader to carry out a metaphoric transfer of meaning that is steered by co-text and context information". See Ruben Zimmermann, How to understand the parables of Jesus. A paradigm shift in parable exegesis, in Acta Theologica, 1/2009, p, 170, apud https://oalibrary.org/papers

${ }^{19}$ Dorin OPRIS, op. cit., p. 196.

${ }^{20}$ Norman PERRIN, The Kingdom of God in the teaching of Jesus, Cheap Edition, London, 1996, pp. 62-63.

${ }^{21}$ C. H. DodD, The Kingdom of God and history, George Allen \& Unwin Ltd., London, 1938, p. 33.
} 
Like Klyne Snodgrass said, , the purpose of the parables is not to teach theology; if that were the case, direct communication would have been used. But, the parables are theological, and virtually no where is Scripture intended to teach theology in a technical sense. Scripture embeds a theology and assumes a theology in seeking to move people to right relation and right living with God"22.

The man looking for Christ does not look for beautiful words and does not find only beautiful words. Following Christ is not just beauty but also sacrifice; and where this is manifested, namely where Christ is being followed, the gifts received are multiplied by the thousand; there is also material not just spiritual abundance. When man is wise and looks for God, he enjoys not just spiritual but also material goods.

\section{CONCLUSION}

Amazed by the teachings they were listening to and the wonderful actions they were seeing, the multitudes call our Savior Jesus Christ "the Teacher" (Jn. 6:14) and "the Prophet" (Luke 7: 16), the Prophet announced by Moses (Deut. 18: 15-18). His apostles, but also His adversaries, were calling Him "Teacher" (Mt. 8: 19; Mk. 10: 35); since then and for eternity He remains the Prophet of the truth and the Teacher of the world, the prophet of all the prophets and the Teachers of all the teachers, and His teaching is, above all, His person.

Our Savior Christ, the Teacher by excellence, has revealed to the world the Evangel, namely the good news of the divine mercy coming on man to save, and the eternal truths regarding God's Person and His eternal Kingdom. Christ has taken care to teach to the people God's Word, in such a manner that this Word may be easily understandable and assimilable by the listeners, being attentive and very perceptive regarding the needs of the human being, to whom He descended so lovingly.

In his mission, Christ our Lord has in view to transmit all that man needs to know about God, about the world, about his own person, the essentials able to lead man to salvation. For this reason, more than in any part of the Evangel, in the parables we find theological truths that our Savior wraps up in perfect literary forms adapted to man's power of understanding.

\section{BIBLIOGRAPHY:}

[1] Biblia sau Sfânta Scriptură, IBMBOR, Bucureşti, 2015

[2] Sfânta Scriptură sau Biblia jubiliară a Sfântului Sinod, editor IPS Bartolomeu Anania, (București: IBMBOR Publishing House, ediţie jubiliară, 2001).

[3] ARION, Pr. Prof. Univ. Dr. Leon, Comentarii la Sfânta Evanghelie după Matei, Ed. ASA, București, 2007

[4] Alexandrinul, Clement, Pedagogul, in Scrieri, partea I, trad. de Dumitru Fecioru, colecția P.S.B., vol.4, E.I.B.M.B.O.R., București, 1982

[5] ANDrutsos, Hristu, Dogmatica Bisericii Ortodoxe răsăritene, Editura și tiparul Tipografiei Arhidiecezane, Sibiu, 1930

[6] CĂLugăru, Pr. Prof. Dumitru, Catehetica, ediția a IV-a, Editura "Renașterea", Cluj-Napoca, 2005

[7] Chițescu, Prof. N.; Todoran, Pr. Prof. Isidor; Petreuță, Pr. Prof. I., Teologia dogmatică şi simbolică, vol. II, Ed.Renaşterea, Cluj-Napoca, 2005

[8] Constantinescu, Pr. Prof. Ioan, Studiul Noului Testament, E.I.B.M.B.O.R., București, 2002

${ }^{22}$ Klyne SnODgrass, Prophets, parables, and theologians, in Bulletin for Biblical Research 18.1 (2008), p. 67, apud. https://www.ibr-bbr.org/files 
[9] Cornițescu, Pr. Prof. Dr. Constantin, Studiul biblic al Noului Testament, Ed. Europolis, Constanța, 2005

[10] DoDD, C. H., The Kingdom of God and history, George Allen \& Unwin Ltd., London, 1938

[11] GaleriU, Pr. Prof. Dr. Constantin, Mântuitorul Iisus Hristos, Invățătorul nostru suprem, in rev. "Ortodoxia", no. 1/1983, pp. $32-41$

[12] GordOn, Pr. Lect. Dr. Vasile, Predica Ocazională, E.I.B.M.B.O.R., București, 2001

[13] OPRIȘ, Dorin, Dimensiuni creștine ale pedagogiei moderne, ediția a III-a, Ed. Didactică şi Pedagogică, R. A., București, 2012

[14] PERrIN, Norman, The Kingdom of God in the teaching of Jesus, S.C.M. Cheap Edition,London, 1996

[15] StăniloAe, Pr. Prof. Dr. Dumitru, Teologia Dogmatică Ortodoxă, vol. II, ediția a II - a, EIBMBOR, București, 1997

[16]ZIMMERMANN, Ruben, How to understand the parables of Jesus. A paradigm shift in parable exegesis, in Acta Theologica, 1/2009

[17] http://www.agoracrestina.ro/biblioteca/nicolae_codrea-iisus-hristos-invatatorul-in-opera-luiilarion-v-felea-.html

[18] https://oalibrary.org/papers

[19] https://www.ibr-bbr.org/files 